\title{
Alternative conifer release treatments affect small mammals in northwestern Ontario
}

\author{
by R.A. Lautenschlager, F. Wayne Bell and Robert G. Wagner ${ }^{1}$
}

\begin{abstract}
Density changes of small mammals responding to different conifer release treatments (motor-manual [brush saw] cutting; mechanical [Silvana Selective] cutting; helicopter-applied herbicides [Release ${ }^{\circledR}$ (a.i. triclopyr), Vision ${ }^{\circledR}$ (a.i. glyphosate)]; controls [no treatment] were quantified. A total of 4,851 small mammals were captured and released during the three-year study. The most commonly captured ( $81 \%$ of total) species were: shrews (masked [Sorex cinereus Kerr], pygmy [S. hoyi Baird], arctic $S$. arcticus Kerr]), southern red-backed voles (Clethrionomys gapperi Vigors), and deer mice (Peromyscus maniculatus Wagner). Northern short-tailed shrews (Blarina brevicauda Say), eastern (Tamias striatus L.) and least (T. minimus Bachman) chipmunks, meadow voles (Microtus pennsylvanicus Ord), ermine (Mustela erminea L.), and meadow jumping mice (Zapus hudsonius Zimm.) were common. Shrew (masked, pygmy, arctic, short-tailed) densities were statistically unaffected by these treatments. Redbacked vole densities were highest on control plots during the first post-treatment growing season, and highest on control and Vision ${ }^{\bigotimes}$ plots during the second post-treatment growing season. During the first two growing seasons after treatment, deer mouse densities were highest on Silvana Selective plots; eastern chipmunk densities were highest on control, Vision and Silvana Selective plots; least chipmunk densities were highest on Vision ${ }^{\circledR}$ and Release ${ }^{\circledR}$ plots; and meadow vole densities were highest on Release ${ }^{\circledR}$ plots. Small mammal responses to the alternative conifer release treatments examined were species specific one and two-growing seasons post-treatment, but similar to responses common to the standard (Vision ${ }^{\circledR}$ herbicide) conifer release treatment.
\end{abstract}

Key words: conifer release, Fallingsnow Ecosystem Project, glyphosate, herbicides, Release ${ }^{\circledR}$, small mammals, spruce plantation, triclopyr, vegetation management alternatives, Vision ${ }^{\circledR}$, wildlife habitat
Cette étude s'est penchée sur les changements de densité survenus parmi les petits mammiferes suite à la réalisation de différent traitements de dégagement des conifères: dégagement manuel mécanisé [scie débroussailleuse]; dégagement mécanisé [Silvana Selective]; pulvérisions de phytocides au moyen d'un hélicoptère [Release ${ }^{8}$ (é.a. triclopyr) et Vision ${ }^{\circledR}$ (é.a. glyphosate)]; et parcelles témoins [aucun traitement]. Un total de 4851 petits mammifêres furent capturés et relâchés au cours des trois années de l'étude. Les espèces les plus souvent capturées étaient: les musaraignes (cendrées \{Sorex cincrous Kerr[, pygmées [S. hovi Baird], artiques $\{S$. articus Kerr], des campagnols à dos roux (Clethrionomys gapperi Vigors), et des souris sylvestres (Peromyscus maniculatus Wagner). Les musaraignes à queue courte (Blanira brevicauda Say), des tamias rayés (Tamias striatus L.) et des tamias mineurs (T. minimus Bachman), ainsi que des campagnols des champs (Microtus pennsylvanicus Ord), des helettes à queue courte (Mustela erminea $\mathrm{T}$.) et des souris sauteuses des champs (Zapus hudsonius) Zimm.) étaient fréquentes. Les densités des musaraignes (cendrées, pygmées, artiques et à petite queue) ne furent statistiquement perturbées par ces traitements. Les densités de campagnol à dos roux étaient les plus élevées dans les parcelles témoins au cours de la première année de croissance après le traitement, et les plus élevées dans les parcelles témoins et les parcelles traitées au Vision ${ }^{8}$ au cours de la deuxième année de croissance après traitement. Au cours des deux premières années de croissance après traitement, les densités de souris sylvestres furent les plus élevées dans les parcelles traitées au moyen du Silvana Selective; les densités de tamias rayés furent les plus élevées dans les parcelles témoins, et dans les parcelles traitées au moyen du Vision ${ }^{\circledR}$ et du Silvana Selective; les densités de tamias mineurs furent les plus élevées dans les parcelles traitées au Vision ${ }^{\circledR}$ et au Release $^{\circledR}$; et les densités de campagnols des champs furent les plus élevées dans les parcelles traitées au Release ${ }^{\circledR}$. Les réactions des petits mammiferes par rapport aux traitements alternatifs de dégagement des conifères étudiés étaient spécifiques aux espèces une et deux années de croissance après traitement, mais semblables aux réactions habituelles rencontrées lors de l'utilisation courante du traitement de dégagement des conifères (phytocide Vision ${ }^{(8)}$ ).

Mots clés: dégagement de conifères, projet écosystémique de Fallingsnow, phyphosate, phytocides, Release ${ }^{\circledR}$, petits mammifères, plantation d'épinette, triclopyr, alternatives de contrôle de la végétation, Vision ${ }^{\circledR}$, habitat faunique

\section{Introduction}

Forest regeneration success in many North American ecosystems commonly depends on managing non-crop vegetation ("competition") (Walstad and Kuch 1987). In Canada aerial conifer release ("tending") with herbicides is the most commonly used forest vegetation management practice (Campbell 1990). Herbicides are preferred because they are the least expensive silvicultural treatment for increasing forest crop yield (Campbell 1990). Although foresters have relied on herbicides to control non-crop vegetation for the last three decades (Stewart et al. 1984), this practice has met

${ }^{1}$ Ontario Ministry of Natural Resources, Ontario Forest Research Institute, 1235 Queen St. East, Sault Ste. Marie, Ontario, Canada P6A 5N5. with increasing public resistance (Walstad and Dost 1984; Lautenschlager 1986; Campbell 1990; Freedman 1991; Wagner 1993). In 1989, $71 \%$ of Canadians thought "chemicals in the forest" were an unacceptable form of forest management (Environics Research Group 1989); in 1994, 80\% of Ontario's public stated that aerial herbicide applications for forest management were unacceptable (Decision Research 1995).

In the early 1990 s, concerns related to the increasing use of herbicides for forest management in Ontario contributed to the development of the Vegetation Management Alternatives Program (VMAP), part of the Ontario Ministry of Natural Resources Sustainable Forestry Initiative (Wagner 1992). The VMAP program seeks to develop forest management approaches (alternatives) that reduce dependence on aerially 
applied herbicides. After possible alternatives are identified, they are tested against standard (aerial) herbicide technologies for efficacy (non-crop reduction [short-term], crop tree growth [longer-term]) and to determine their environmental consequences.

This paper reports results of one aspect (small mammals) of a multi-disciplinary, integrated, large-scale, operational project (the Fallingsnow Ecosystem) (Lautenschlager et al. 1997), designed to document the environmental (abiotic and biotic) consequences of alternative conifer-release treatments in young spruce (Picea spp.) plantations. Because small mammals are ubiquitous, depend on plants for food and cover, periodically consume invertebrates, are important foods for avian and terrestrial predators (Sullivan 1990), and are sensitive to microhabitat changes (Miller and Getz 1977; Dueser and Shugart 1978; Yahner 1986), their responses to alternative coniferrelease treatments interest forest ecologists and managers.

The objective of this study was to determine the effects of conifer-release, using standard herbicide technology (helicopterapplied Vision ${ }^{(82}$, a.i. glyphosate) (Campbell 1990) and alternative treatments, on small mammal species composition and densities, as part of the larger Fallingsnow Ecosystem Project. Although 14 published studies have examined the effects of conifer-release with herbicides on small mammals, many lacked pre-treatment data and/or had minimal replication (Lautenschlager 1993). Also, except for Lautenschlager et al. (1995) and Runciman and Sullivan (1996), no studies have compared the effects of aerially applied herbicides with one or more of the proposed alternatives (motor-manual and mechanical cutting, different herbicides, and/or different application techniques). Comparative studies are critical to forest managers attempting to make informed decisions about the effects of coniferrelease alternatives on costs (Bell et al. 1997a), crop growth, and ecosystem structure and function. (Documenting crop growth and ecosystem structure and function will require longerterm study, such as that being conducted by cooperators in the Fallingsnow Ecosystem Project [Lautenschlager et al. 1997]. Designing and recommending alternative forest management approaches, that balance concerns of the public and forest managers [environmental realities and treatment efficacy], will be possible only after this analysis is complete.)

\section{Methods}

\section{Study Area and Treatments}

The study area for the Fallingsnow Ecosystem Project (Lautenschlager et al. 1997), of which this small mammal research is one part, is $60 \mathrm{~km}$ southwest of Thunder Bay, Ontario, in Fraleigh Township. The area is part of the Great Lakes-St. Lawrence forest region (Rowe 1972). The randomized complete block design consists of four separate 28 to 52 ha blocks that were clearcut harvested and planted (with bareroot white spruce [Picea glauca \{Moench\} Voss] [three blocks] and black spruce [P. mariana (Mill.) B.S.P.] [one block]) four to seven years before the project began. Blocks, and plots within blocks, vary in elevation and topography; soils are predominately imperfectly drained silt loam, but range from poorly to excessively drained (Simpson et al. 1997). Blocks range from 0.7 to $1.5 \mathrm{~km}$ apart, and each contains the following coniferrelease alternatives: (1) motor-manual release with brush saws applied in mid-late October 1993; (2) mechanical release

\footnotetext{
${ }^{2}$ Trademark of Monsanto.

${ }^{3}$ Trademark of DowElanco.
}

with the Silvana Selective/Ford Versatile applied between late October and early November 1993; (3) Release ${ }^{\circledR 3}$ (triclopyr [a selective herbicide] @ $1.9 \mathrm{~kg}$ a.e. $\mathrm{ha}^{-1}$ ) applied (16 August 1993) by helicopter (Bell 206); (4) Vision ${ }^{\circledR}$ (glyphosate [a broadspectrum herbicide] @ $1.5 \mathrm{~kg}$ a.e. ha ${ }^{-1}$ ) applied (16 August 1993) by helicopter (Bell 206); and (5) control (no treatment). Designated treatment plots ranged from 3.3 to 12.4 ha, and percentage of area treated ranged from $57 \%$ to $100 \%$. Aerial herbicide applications treated less $(\sim 75 \%)$ of the designated treatment area than the brush saw and Silvana Selective treatments ( 90\%) (Bell et al. 1997a). See Bell et al. (1997a,b), in this volume, for additional details about site, treatments, and treatment effects on vegetation; see Thompson et al. (1997) for herbicide application, deposit, and vertical distribution details.

\section{Small Mammal Trapping}

Small mammals were live-trapped with 49 traps (Sherman $-7.5 \times 9.0 \times 23.5 \mathrm{~cm})$ plot $^{-1}\left(245\right.$ traps block $^{-1} ; 980$ total $)$. Individual traps were placed $12 \mathrm{~m}$ apart in the center of plots on $7 \times 7$ trap grids. The closest traps on separate trap grids were a minimum of $100 \mathrm{~m}$ apart. Traps were baited with peanut butter and oatmeal, supplied with coarse brown cotton, and set so that minimal treadle pressure was required to close the trap. When the "draw"4 to outer traps was included, these grids sampled approximately 1 ha. Traps were examined morning and evening for five consecutive days during early August (preherbicide treatments) and September [post-herbicide, but pre-cutting (brush saw + Silvana) treatments] 1993, and midJune, late-July, and late-August 1994 (first post-treatment growing season), and mid-June and late-July 1995 (second posttreatment growing season). Trapped animals were identified to species, sexed, aged, weighed, and reproductive condition and unique features noted. Animals were ear-tagged (National Band \& Tag 1005-1, monel steel) and released at the point of capture.

\section{Statistical Analysis and Nomenclature}

The minimum number of animals known to be alive (density) (Krebs 1966) was calculated, based on captures, for small mammal species during each trapping period. These density data were analyzed as follows: (1) means and standard errors of non-transformed density data, and (2) general linear models, analysis of co-variance (pre-treatment [1993] average as the co-variate), with Duncan's multiple range test. Statistically significant $(P<0.05)$ results are discussed. Common and scientific names for small mammals are those used by Kurta (1995), and Fernald (1970) for plants.

\section{Results}

Fourteen small mammal species were captured. In 1993, 1,459 individuals were captured during the two trapping periods (August and September); in 1994, 2,141 were captured

\footnotetext{
4 "Draw" or "edge effect", an inherent problem associated with trapping grids, is related to an individual species' home range size (Bondrup-Nielsen 1983), and trapping season. The estimate of draw, for this study, was based on a comparison of the average capture rate for traps located on the outside edges of the trap grids with the rates for traps on the inside of the grids. Outside traps, depending on season, were up to twice as successful as inside traps, and inside traps sampled $6 \mathrm{~m}$ in every direction $\left(144 \mathrm{~m}^{2}\right)$. It was assumed that outside traps sampled a $50 \%$ greater area than inside traps $\left(216 \mathrm{~m}^{2}\right.$, or $6 \mathrm{~m}$ on the inside but $12 \mathrm{~m}$ on the outside). Hence, a trap line (seven traps) sampled the interior $(6 \times 12 \mathrm{~m})$, plus the exterior $(2 \times 12 \mathrm{~m})$ for a total of $96 \mathrm{~m}$, and each grid sampled approximately 1 ha $(96 \mathrm{~m} \times 96 \mathrm{~m})$.
} 


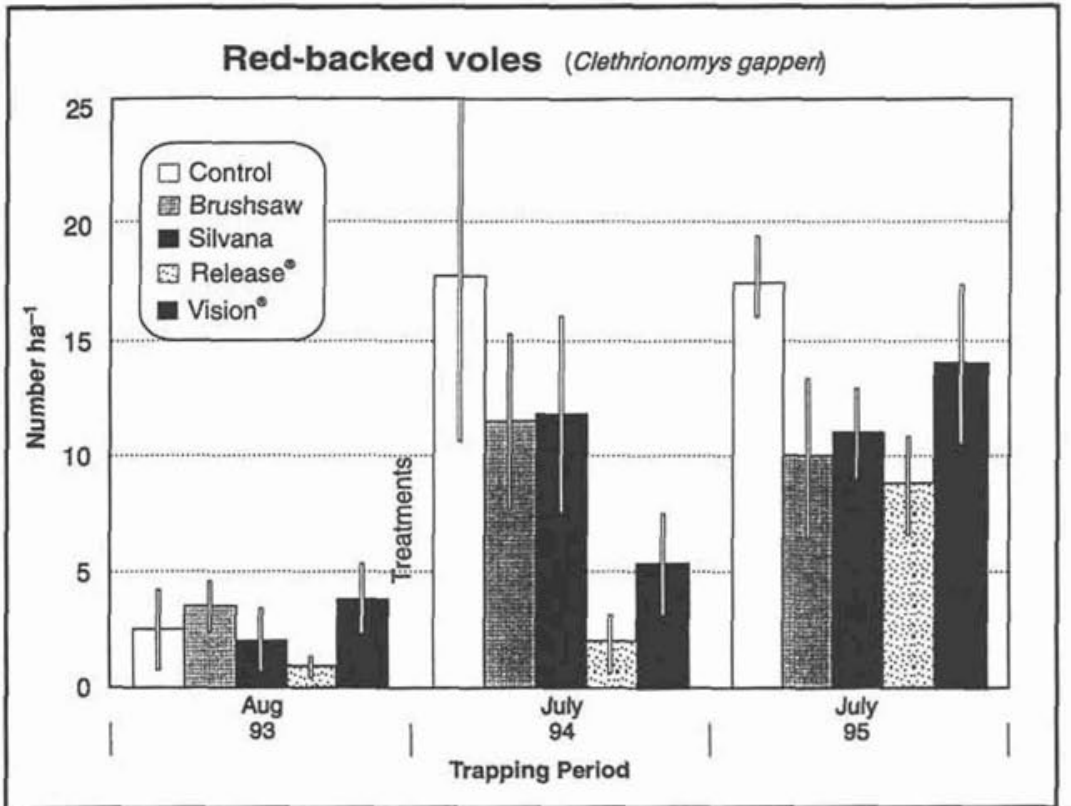

Fig. 1. Response $(X \pm \mathrm{SE}, N=4)$ of red-backed voles (Clethrionomys gapperi) to alternative conifer release treatments. (Note: To facilitate comparison among years and treatments, only mid-summer (July, August) means are presented.)
Fig. 2. Response $(X \pm \mathrm{SE}, N=4)$ of deer mice (Peromyscus maniculatus) to altemative conifer release treatments. (Note: To facilitate comparison among years and treatments, only mid-summer (July, August) means are presented.)

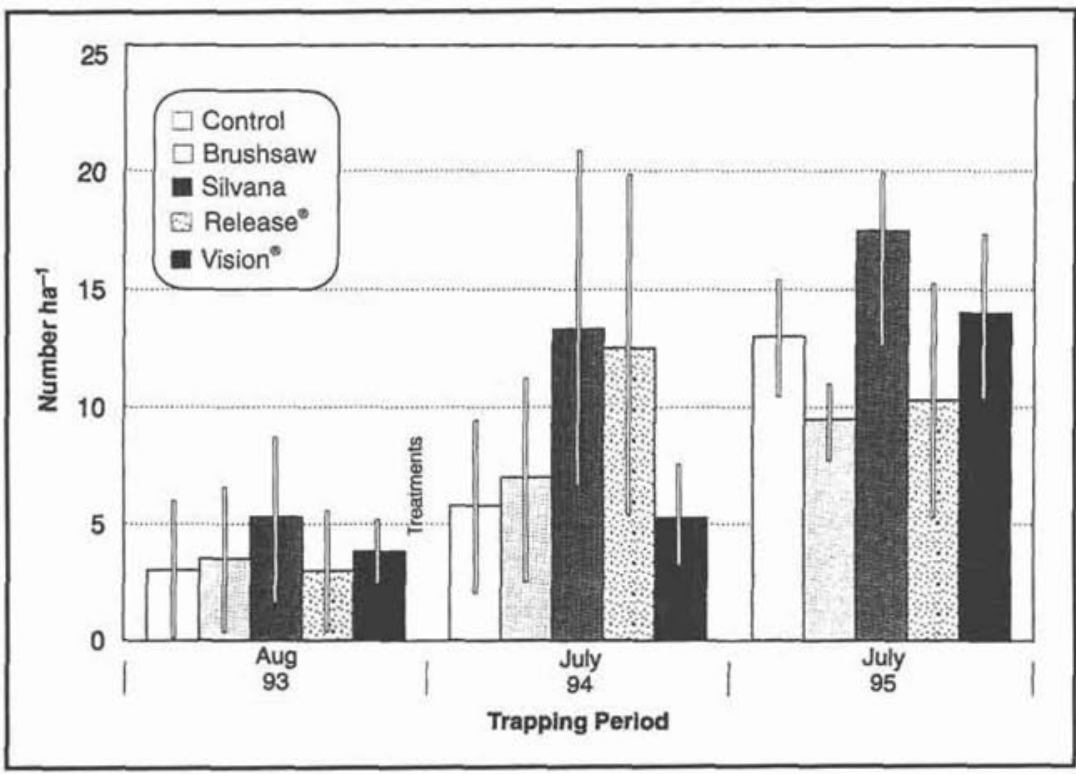

during three trapping periods (June, July, September); and in 1995, 1,251 were captured during two trapping periods (June and July). Percentage of total captures by species in 1993, 1994, and 1995 respectively were: Sorex spp. (masked [Sorex cinereus Kerr], pygmy [S. hoyi Baird] ${ }^{5}$, arctic [S. arcticus Kerr]) $(39.7,45.2,19.0)$; southern red-backed voles (Clethrionomys gapperi Vigors) $(24.8,21.2,28.1)$; deer mice (Peromyscus maniculatus Wagner) $(18.6,14.8,28.3)$; northern short-tailed shrews (Blarina brevicauda Say) $(8.3,0.7,0.2)$; eastern chipmunks (Tamias striatus L.) $(4.0,6.1,12.9)$; least chipmunks (T. minimus Bachman) $(1.6,4.5,6.6)$; meadow voles (Microtus pennsylvanicus Ord) $(1.8,3.1,2.4)$; ermine (Mustela erminea L.) $(0.5,1.6,1.5)$; meadow jumping mice (Zapus hudsonius Zimm.) $(0.3,0.4,0.8)$. In addition two heather voles (Phenacomys

${ }^{5}$ Masked and pygmy shrews were not differentiated in the field and were identified as Sorex spp. when captured. intermedius Merriam), one rock vole (Microtus chrotorrhinus Miller), and one water shrew (S. palustris Rich.) were caught during this study.

Densities of all shrew species (masked and pygmy [combined], arctic, and short-tailed) were statistically unaffected by these treatments. Treatments did affect (Duncan's, $P<0.05$ ) mean densities of red-backed voles, deer mice, and least chipmunks (Table 1, Figs. 1-3). (Note that the apparent decrease in densities of most species between 1994 and 1995 is an artefact related to the seasonally lower densities associated with the 1995 sampling times. Small mammals were trapped in mid-June, late-July, and late-August 1994, but only during mid-June and late-July in 1995. The August/September trapping period consistently has the highest annual density [Table 2], and was not part of the 1995 sample.)

Red-backed vole densities were affected during both the first and second post-treatment growing seasons (Table 1). Densities 


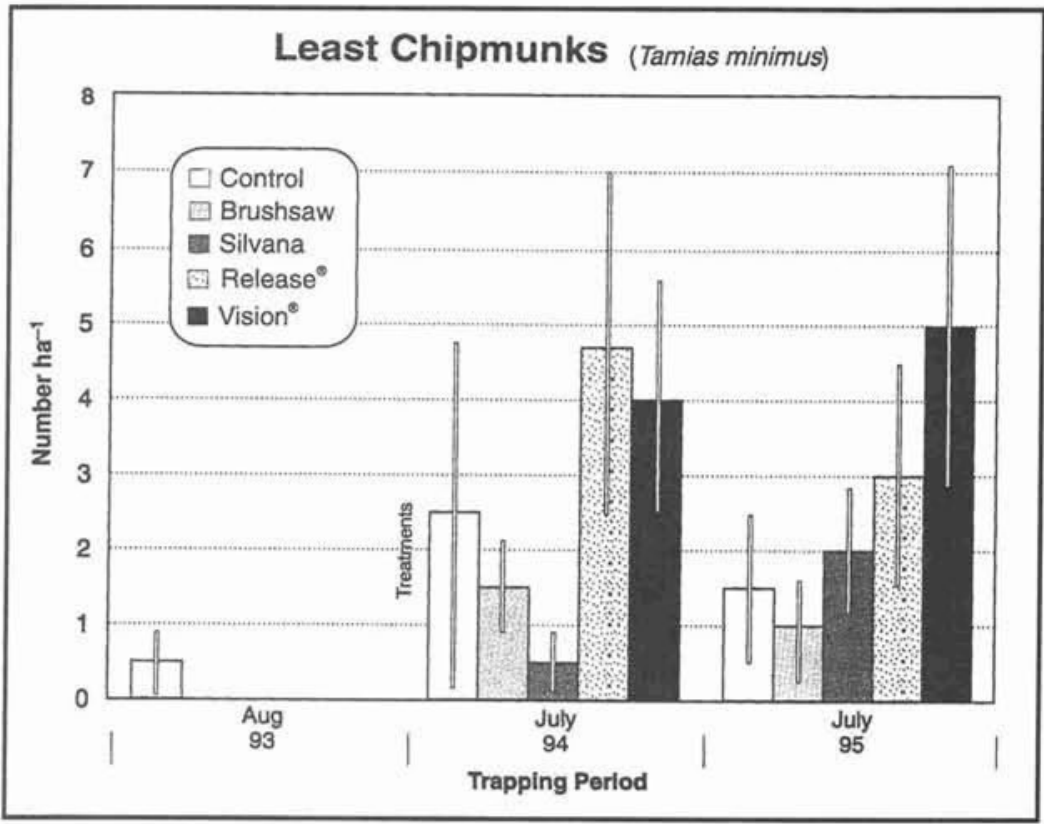

Fig. 3. Response $(X \pm \mathrm{SE}, N=4)$ of least chipmunks (Tamias minimus) to alternative conifer release treatments. (Note: To facilitate comparison among years and treatments, only mid-summer (July, August) means are presented.) were highest on control, lower but statistically similar in brush saw and Silvana Selective, lower still on Vision ${ }^{\circledR}$, and lowest on Release ${ }^{\circledR}$ plots during the first post-treatment growing season (Fig. 1). During the second post-treatment growing season red-backed vole densities were highest on the control and Vision ${ }^{\circledR}$, lower but statistically similar on the Silvana Selective and brush saw plots, and lowest on Release ${ }^{\circledR}$ plots.

Deer mouse densities were statistically unaffected during the first post-treatment growing season but during the second post-treatment growing season densities were highest on Silvana and lowest on the Vision ${ }^{18}$ plots (Table 1). Densities on Release ${ }^{\circledR}$, control, and brush saw were statistically similar and confidence intervals overlapped both the highest (Silvana Selective), and lowest (Vision $\left.{ }^{8}\right)$ densities observed.

Eastern chipmunk densities were highly variable but statistically unaffected by these treatments during the first two growing seasons after treatment (Table 1). Least chipmunk densities were statistically unaffected during the first post-treatment growing season, but seemed to respond positively to both herbicide treatments (Table 1, Fig. 3). During the second post-treatment growing season, least chipmunk densities were highest on Vision ${ }^{8}$ plots, lower but statistically similar on Release ${ }^{\circledR}$, control, and Silvana Selective plots, and lowest on brush saw plots.

Meadow vole densities were highly variable, but statistically unaffected by these treatments (Table 1). Densities were, however, consistently highest on Release ${ }^{\circledR}$ plots during both the first and second post-treatment growing seasons (Table 2). Although ermine, meadow jumping mice, and heather voles were not uncommon, too few were caught during this study to draw conclusions about the effects of treatments on these species.

\section{Discussion}

No signs of direct treatment effects (abnormalities or death) were noted during this study. Existing research (Lautenschlager 1993) has concluded that density changes following herbicide treatments are related to habitat changes (changes in vegetation structure and composition) that indirectly affect small mammal populations.
The literature documenting effects of conifer-release treatments on shrew species is inconsistent. Borrecco et al. (1979) reported that one year after conifer release with a variety of herbicides, Trowbridge shrew (Sorex trowbridgii Baird) densities were higher in treated areas, and Sullivan and Sullivan (1982) reported that glyphosate had no negative effects on shrews during the growing season after treatment. Santillo et al. (1989), however, reported that insectivores (primarily $S$. cinereus) were less abundant on Roundup ${ }^{\circledR}$ (a.i. glyphosate) -treated plots for three growing seasons after treatment.

1,970 shrews were caught, representing four species (masked and pygmy, arctic, short-tailed), during this three year study. Eighty-two percent of the shrews captured were masked or pygmy. Although no attempt was made to identify these to species in the field, an examination (teeth under a dissecting microscope) of those that died in traps revealed that $80 \%$ of the dead Sorex spp. were masked (S. cinereus) and $20 \%$ were pygmy (S. hoyi). When caught and released in the field these very similar species were combined into Sorex spp.

Although the shrew species identified responded differently to the treatments, they were statistically unaffected (Table 1). Like red-backed voles, but to a lesser degree, Sorex spp. densities decreased following vegetation reductions (Table 2), either because of the reductions themselves, the associated microclimatic changes (increased near-ground temperatures and decreased relative humidity [Reynolds et al. 1997]), or because of changes in available food. Microclimate differences, however, are not as dramatic on this more productive spruce site as they are on more open, less productive pine sites. Indeed, shrews were so uncommon in one jack pine (Pinus banksiana Lamb.) plantation study area (Lautenschlager et al. 1995), that there were insufficient numbers for testing comparisons among treatments.

Studies of the effects of herbicides on red-backed voles (Clough 1987; D'Anieri et al. 1987; Freedman et al. 1988; Santillo et al. 1989; McMillan et al. 1990; Lautenschlager et al. 1995) consistently demonstrate reductions in density during the 
Table 1. Means, and mean separation (Duncan's multiple range), $F$, and $P$ values from ANCOVA (pre-treatment [1993] captures $=$ covariate) for treatment and time effects on small mammal species captured during the first (4) and second (5) post-treatment growing seasons in the Fallingsnow study area

\begin{tabular}{|c|c|c|c|c|c|c|c|}
\hline Species & Control & Brush saw & Silvana & Release® & Vision® & $F$ Value & $P>F$ \\
\hline $\begin{array}{l}\text { Masked and }(4)^{1} \\
\text { pygmy shrews } \\
\end{array}$ & $\begin{array}{c}16.25 a^{4} \\
6.38 a\end{array}$ & $\begin{array}{r}17.17 a \\
6.63 a\end{array}$ & $\begin{array}{r}14.83 a \\
4.14 a\end{array}$ & $\begin{array}{r}15.08 a \\
2.88 a\end{array}$ & $\begin{array}{r}10.58 a \\
3.75 a\end{array}$ & $\begin{array}{l}1.47 \\
1.06\end{array}$ & $\begin{array}{l}0.2620 \\
0.4232\end{array}$ \\
\hline $\begin{array}{l}\text { Arctic (4) } \\
\text { shrew (5) }\end{array}$ & $\begin{array}{l}1.83 a \\
1.13 a\end{array}$ & $\begin{array}{l}1.75 a \\
2.00 a\end{array}$ & $\begin{array}{l}1.92 a \\
1.00 a\end{array}$ & $\begin{array}{l}2.92 a \\
1.25 a\end{array}$ & $\begin{array}{l}2.33 a \\
0.63 a\end{array}$ & $\begin{array}{l}1.34 \\
1.72\end{array}$ & $\begin{array}{l}0.3043 \\
0.1937\end{array}$ \\
\hline $\begin{array}{l}\text { Short-tailed (4) } \\
\text { shrew (5) }\end{array}$ & $\begin{array}{l}0.00 a \\
0.13 a\end{array}$ & $\begin{array}{l}3.25 a \\
0 a\end{array}$ & $\begin{array}{l}0 a \\
0 a\end{array}$ & $\begin{array}{l}0 a \\
0.13 a\end{array}$ & $\begin{array}{l}0.25 a \\
0.13 a\end{array}$ & $\begin{array}{l}0.76 \\
0.83\end{array}$ & $\begin{array}{l}0.5957 \\
0.5518\end{array}$ \\
\hline $\begin{array}{l}\text { Red-backed (4) } \\
\text { vole (5) }\end{array}$ & $\begin{array}{l}14.92 a \\
12.38 a\end{array}$ & $\begin{array}{r}11.08 a, b \\
6.75 a, b\end{array}$ & $\begin{array}{r}10.58 a, b \\
7.00 a, b\end{array}$ & $\begin{array}{l}2.92 c \\
5.63 b\end{array}$ & $\begin{array}{r}5.58 b, c \\
11.13 a, b\end{array}$ & $\begin{array}{l}8.18 \\
1.89\end{array}$ & $\begin{array}{l}0.0009 \\
0.1601\end{array}$ \\
\hline $\begin{array}{l}\operatorname{Deer}(4) \\
\text { mouse }(5)\end{array}$ & $\begin{array}{l}5.75 a \\
8.63 a, b\end{array}$ & $\begin{array}{l}6.83 a \\
7.25 a, b\end{array}$ & $\begin{array}{l}12.17 a \\
12.88 a\end{array}$ & $\begin{array}{l}11.17 a \\
9.13 a, b\end{array}$ & $\begin{array}{l}5.88 a \\
4.50 b\end{array}$ & $\begin{array}{l}6.52 \\
4.43\end{array}$ & $\begin{array}{l}0.0025 \\
0.0125\end{array}$ \\
\hline $\begin{array}{l}\text { Eastern (4) } \\
\text { chipmunk (5) }\end{array}$ & $\begin{array}{l}4.33 a \\
5.75 a\end{array}$ & $\begin{array}{l}2.17 a \\
2.38 a\end{array}$ & $\begin{array}{l}4.33 a \\
4.25 a\end{array}$ & $\begin{array}{l}1.67 a \\
3.00 a\end{array}$ & $\begin{array}{l}4.75 a \\
4.13 a\end{array}$ & $\begin{array}{l}5.33 \\
3.25\end{array}$ & $\begin{array}{l}0.0060 \\
0.0373\end{array}$ \\
\hline $\begin{array}{l}\text { Least (4) } \\
\text { chipmunk (5) }\end{array}$ & $\begin{array}{l}2.25 a \\
1.88 a, b\end{array}$ & $\begin{array}{l}1.42 a \\
0.63 b\end{array}$ & $\begin{array}{l}0.92 a \\
1.50 a, b\end{array}$ & $\begin{array}{l}2.67 a \\
2.75 a, b\end{array}$ & $\begin{array}{l}3.00 a \\
3.63 a\end{array}$ & $\begin{array}{l}4.24 \\
4.28\end{array}$ & $\begin{array}{l}0.0148 \\
0.0143\end{array}$ \\
\hline $\begin{array}{l}\text { Meadow (4) } \\
\text { vole (5) }\end{array}$ & $\begin{array}{l}1.33 a \\
0.63 a\end{array}$ & $\begin{array}{l}1.58 a \\
0.25 a\end{array}$ & $\begin{array}{l}0.50 a \\
0 a\end{array}$ & $\begin{array}{l}2.25 a \\
2.50 a\end{array}$ & $\begin{array}{l}0.67 a \\
0.38 a \\
\end{array}$ & $\begin{array}{l}3.59 \\
2.79 \\
\end{array}$ & $\begin{array}{l}0.0268 \\
0.0595 \\
\end{array}$ \\
\hline
\end{tabular}

$1(4)$ and $(5)=1994$ and 1995 respectively, 1993 captures used as the covariate.

2 Includes Sorex cinereus and $S$. hoyi combined.

${ }^{3}$ The apparent decrease in densities between 1994 and 1995 is an artefact related to the seasonally lower densities associated with the 1995 sampling times. Small mammals were trapped in mid-June, late-July, and late-August 1994, but only during mid-June and late-July in 1995. The August/September trapping period consistently has the highest yearly density, and was not part of the 1995 sample.

${ }^{4}$ Means followed by the same letter in a row are not significantly $(P<0.05)$ different among treatments.

growing season following treatment. Here, red-backed vole densities were reduced on Vision ${ }^{\circledR}$ and Release ${ }^{\circledR}$ plots during the first post-treatment growing season. By the second posttreatment growing season, however, densities were similar on control and Vision ${ }^{\circledR}$, lower but similar on Silvana and brush saw, and significantly lower than control on the Release ${ }^{\circledR}$ plots. In these spruce plantations red-backed vole density decreases seem to be associated with the removal of woody vegetation. Woody vegetation increased on control plots during this study, but was reduced dramatically on all treated plots during the first post-treatment growing season (Bell et al. 1997b). Of all the treatments, Release ${ }^{\circledR}$ plots had the greatest increase in forb, and grass/sedge vegetation following treatment (Bell et al. 1997b), and it may be that the decrease in red-backed vole density following that treatment was related to this abundance of near-ground vegetation.

Lautenschlager et al. (1995) reported that red-backed vole densities in a six-year-old jack pine plantation were reduced by an operational Vision ${ }^{\circledR}$ treatment during the first and second post-treatment growing seasons, but that by the third post-treatment growing season densities were within the range of controls. Here, red-backed voles seemed to recover from the operational Vision ${ }^{\circledR}$ treatment by the second posttreatment growing season, potentially because the more productive character of the soils in this spruce plantation produced vegetation biomass (food and cover) more quickly and in greater amounts than was produced on the coarser soils in the jack pine study. This may help explain differences among results previously reported, and supports Lautenschlager's (1993) argument that productive sites provide post-disturbance wildlife habitat sooner than less productive sites.
Deer mouse densities commonly increase following herbicide treatments (Borrecco et al. 1979; McMillan et al. 1990; Milton and Towers 1990). In this study deer mouse densities were greatest on Silvana Selective, lower but similar on Release ${ }^{\circledR}$, control, and brush saw plots, and significantly lower than Silvana Selective on the Vision ${ }^{\circledR}$ plots two growing seasons after treatment. The Silvana Selective and Vision ${ }^{\circledR}$ treatments both reduced non-crop woody vegetation, but by different degrees and in different ways. The Silvana Selective treated an average of $89.3 \%$, while Vision ${ }^{\circledR}$ treated an average of $77.3 \%$ of the designated treatment area (Bell et al. 1997a). In addition, following the Silvana Selective and brush saw treatments woody stems were scattered across the ground, while they remained standing (defoliated) after the Vision ${ }^{8}$ and Release ${ }^{(8)}$ treatments. Although the Silvana Selective treatment reduced above-ground woody vegetation as much as any alternative tested, the percentage increase in near-ground vegetation (forb, grass/sedge) was less following the Silvana Selective than any of the other alternative treatments (Bell et al. 1997b). The Vision ${ }^{\circledR}$ treatment reduced non-crop woody vegetation, but that change led to increased near-ground vegetation (Bell et al. 1997b).

These differences in post-treatment vegetation communities, together with the deer mouse population response, suggest that deer mice may benefit from vegetation removal, but that benefit is greatest when near-ground vegetation production is also suppressed. This also may help explain differences among results previously reported but suggests that a knowledge of site productivity alone is insufficient to predict how individual small mammal species will respond to disturbance. Deer mouse densities increased following herbicide and 
Table 2. Small mammal numbers ha ${ }^{-1}(\mathrm{~N}=4)$ by trapping time and treatment, for the most common small mammal species captured pre-treatment (93), and post-treatment (94 and 95)

\begin{tabular}{|c|c|c|c|c|c|c|c|c|c|c|}
\hline \multirow[b]{2}{*}{ Time } & \multicolumn{2}{|c|}{ Control } & \multicolumn{2}{|c|}{ Brushaw } & \multicolumn{2}{|c|}{ Silvana } & \multicolumn{2}{|c|}{ Release $^{8}$} & \multicolumn{2}{|c|}{ Vision ${ }^{(8)}$} \\
\hline & Mean & SE & Mean & SE & Mean & SE & Mean & SE & Mean & SE \\
\hline & \multicolumn{10}{|c|}{ Masked and Pygmy shrews combined } \\
\hline Aug. 1993 & 1.0 & 0.4 & 10.3 & 8.3 & 1.8 & 0.9 & 4.0 & 2.5 & 1.3 & 0.5 \\
\hline Sept. 1993 & 25.8 & 4.2 & 22.8 & 4.0 & 26.5 & 2.7 & 22.3 & 6.5 & 21.3 & 1.9 \\
\hline June 1994 & 1.3 & 0.8 & 1.3 & 0.5 & 1.8 & 0.9 & 1.3 & 0.9 & 0.8 & 0.8 \\
\hline July 1994 & 13.5 & 5.7 & 13.8 & 2.9 & 3.8 & 1.6 & 9.8 & 6.3 & 4.5 & 3.8 \\
\hline Aug. 1994 & 26.5 & 2.5 & 27.0 & 2.2 & 31.3 & 3.9 & 23.0 & 4.0 & 20.0 & 2.5 \\
\hline June 1995 & 0.5 & 0.5 & 0.3 & 0.3 & 1.0 & 0.6 & 1.5 & 1.2 & 0.3 & 0.3 \\
\hline \multirow[t]{2}{*}{ July 1995} & 12.3 & 5.0 & 13.0 & 2.9 & 7.3 & 3.4 & 4.3 & 2.7 & 7.3 & 4.0 \\
\hline & \multicolumn{10}{|c|}{ Arctic shrew } \\
\hline Aug. 1993 & 0 & & 0.5 & 0.3 & 0 & & 0.3 & 0.3 & 0 & \\
\hline Sept. 1993 & 0.5 & 0.3 & 1.8 & 1.1 & 2.8 & 1.3 & 0.3 & 0.3 & 1.8 & 1.2 \\
\hline June 1994 & 0.3 & 0.3 & 0 & & 0 & & 0 & & 0.3 & 0.3 \\
\hline July 1994 & 2.8 & 1.8 & 1.8 & 1.1 & 1.3 & 0.6 & 3.7 & 3.1 & 2.5 & 2.2 \\
\hline Aug. 1994 & 2.5 & 1.5 & 3.5 & 1.9 & 4.5 & 2.3 & 5.0 & 3.2 & 4.3 & 2.4 \\
\hline June 1995 & 0.3 & 0.3 & 0 & & 0 & & 0.3 & 0.3 & 0.3 & 0.3 \\
\hline \multirow[t]{2}{*}{ July 1995} & 2.0 & 1.4 & 4.0 & 2.0 & 2.0 & 1.7 & 2.3 & 2.3 & 1.0 & 0.6 \\
\hline & \multicolumn{10}{|c|}{ Short-tail shrew } \\
\hline Aug. 1993 & 0 & & 0.3 & 0.3 & 0.8 & 0.5 & 0.3 & 0.3 & 1.0 & 0.6 \\
\hline Sept. 1993 & 5.5 & 3.2 & 5.3 & 1.3 & 5.0 & 2.3 & 4.5 & 2.3 & 7.8 & 2.7 \\
\hline June 1994 & 0 & & 0 & & 0 & & 0 & & 0 & \\
\hline July 1994 & 0 & & 0 & & 0 & & 0 & & 0 & \\
\hline Aug. 1994 & 0 & & 3.3 & 3.3 & 0 & & 0 & & 0.3 & 0.3 \\
\hline June 1995 & 0 & & 0 & & 0 & & 0.3 & 0.3 & 0 & \\
\hline July 1995 & 0.3 & 0.3 & 0 & & 0 & & 0 & & 0 & \\
\hline & & & & & Red-b & vole & & & & \\
\hline Aug. 1993 & 2.5 & 1.8 & 3.5 & 1.2 & 2.0 & 1.4 & 0.8 & 0.5 & 3.8 & 1.4 \\
\hline Sept. 1993 & 19.0 & 5.2 & 15.0 & 3.6 & 24.3 & 6.3 & 10.3 & 1.9 & 11.3 & 3.5 \\
\hline June 1994 & 6.8 & 4.5 & 6.0 & 3.0 & 5.0 & 2.0 & 2.5 & 1.6 & 3.5 & 1.3 \\
\hline July 1994 & 17.8 & 7.3 & 11.5 & 3.7 & 11.8 & 4.3 & 2.0 & 1.2 & 5.3 & 2.1 \\
\hline Aug. 1994 & 20.5 & 6.1 & 16.0 & 4.7 & 15.3 & 5.9 & 4.3 & 2.7 & 8.0 & 5.1 \\
\hline June 1995 & 7.8 & 1.5 & 3.5 & 1.7 & 3.5 & 0.6 & 2.5 & 0.9 & 8.5 & 2.8 \\
\hline July 1995 & 17.5 & 2.1 & 10.0 & 3.5 & 11.0 & 2.0 & 8.8 & 2.2 & 14.0 & 3.5 \\
\hline & & & & & Dee & & & & & \\
\hline Aug. 1993 & 3.0 & 3.0 & 3.5 & 3.2 & 5.3 & 3.5 & 3.0 & 2.7 & 3.8 & 1.4 \\
\hline Sept. 1993 & 12.3 & 2.4 & 17.0 & 5.1 & 7.5 & 3.1 & 14.8 & 4.8 & 11.3 & 3.5 \\
\hline June 1994 & 2.5 & 1.9 & 4.0 & 1.5 & 9.3 & 6.00 & 7.0 & 3.6 & 3.5 & 1.3 \\
\hline July 1994 & 5.8 & 3.8 & 7.0 & 4.5 & 13.3 & 6.7 & 12.5 & 7.2 & 5.3 & 2.1 \\
\hline Aug. 1994 & 9.0 & 4.5 & 9.5 & 4.9 & 14.0 & 6.0 & 14.0 & 7.6 & 8.0 & 5.1 \\
\hline June 1995 & 4.8 & 2.8 & 5.5 & 2.0 & 9.5 & 3.1 & 7.5 & 2.8 & 8.5 & 2.8 \\
\hline July 1995 & 13.0 & 2.5 & 9.5 & 1.8 & 17.5 & 4.3 & 10.3 & 5.0 & 14.0 & 3.5 \\
\hline & & & & & Easter & munk & & & & \\
\hline Aug. 1993 & 1.0 & 0.6 & 0.5 & 0.3 & 0 & & 0 & & 0.3 & 0.3 \\
\hline Sept. 1993 & 2.3 & 1.1 & 2.3 & 1.0 & 1.8 & 1.8 & 0 & & 7.3 & 2.5 \\
\hline June 1994 & 2.5 & 1.0 & 1.0 & 0.6 & 3.0 & 1.7 & 0.8 & 0.5 & 3.5 & 1.3 \\
\hline July 1994 & 5.3 & 3.1 & 4.0 & 2.1 & 5.0 & 3.3 & 0.8 & 0.5 & 5.0 & 1.7 \\
\hline Aug. 1994 & 5.3 & 3.7 & 1.5 & 1.0 & 5.0 & 3.2 & 3.8 & 2.4 & 5.8 & 2.0 \\
\hline June 1995 & 3.0 & 1.8 & 1.5 & 1.0 & 1.8 & 1.1 & 1.3 & 0.8 & 1.8 & 1.1 \\
\hline July 1995 & 8.8 & 1.9 & 3.5 & 2.3 & 7.3 & 3.6 & 5.0 & 2.5 & 6.5 & 2.2 \\
\hline & & & & & Least & unk & & & & \\
\hline Aug. 1993 & 0.5 & 0.3 & 0 & & 0 & & 0 & & 0 & \\
\hline Sept. 1993 & 1.8 & 1.2 & 0.5 & 0.5 & 1.0 & 0.7 & 1.8 & 1.8 & 0.8 & 0.8 \\
\hline June 1994 & 1.5 & 1.0 & 1.3 & 0.9 & 0.5 & 0.5 & 2.0 & 1.2 & 0 & \\
\hline July 1994 & 2.5 & 2.2 & 1.5 & 0.6 & 0.5 & 0.3 & 4.7 & 0.6 & 5.0 & 1.8 \\
\hline Aug. 1994 & 2.8 & 1.6 & 1.5 & 1.0 & 1.8 & 1.2 & 1.3 & 2.3 & 4.0 & 1.5 \\
\hline June 1995 & 2.3 & 1.3 & 0.3 & 0.3 & 1.0 & 0.7 & 2.5 & 1.5 & 2.3 & 0.9 \\
\hline July 1995 & 1.5 & 1.0 & 1.0 & 0.7 & 2.0 & 0.9 & 3.0 & 1.5 & 5.0 & 2.1 \\
\hline & & & & & Mea & ole & & & & \\
\hline Aug. 1993 & 0 & & 1.0 & 1.0 & 0.8 & 0.8 & 1.3 & 1.3 & 1.5 & 1.2 \\
\hline Sept. 1993 & 0.5 & 0.5 & 0.3 & 0.3 & 0.3 & 0.3 & 0.3 & 0.3 & 1.0 & 1.0 \\
\hline June 1994 & 0 & & 2.0 & 2.0 & 0.3 & 0.3 & 0.8 & 0.8 & 0 & \\
\hline July 1994 & 0.8 & 0.8 & 0.8 & 0.8 & 0.5 & 0.5 & 3.5 & 2.9 & 1.0 & 0.4 \\
\hline Aug. 1994 & 3.3 & 3.3 & 2.0 & 1.7 & 0.8 & 0.5 & 2.5 & 2.2 & 1.3 & 0.8 \\
\hline June 1995 & 0.5 & 0.5 & 0 & & 0 & & 0.5 & 0.5 & 0.3 & 0.3 \\
\hline July 1995 & 0.8 & 0.8 & 0.5 & 0.5 & 0 & & 4.5 & 4.5 & 0.5 & 0.5 \\
\hline
\end{tabular}


cutting treatments on coarse-textured, well-drained soils in a regenerating jack pine study (Lautenschlager et al. 1995), but not on finer-textured, moister, more productive soils where spruce are commonly planted (this study).

Eastern chipmunks seemed relatively unaffected by Vision ${ }^{\text {(8) }}$ and Silvana Selective treatments during both the first and second post-treatment growing seasons; their densities were, however, reduced following the brush saw and Release ${ }^{\circledR}$ treatments during this time. Sullivan (1990) reported that Townsend chipmunk (Eutamias townsendii) densities declined during the first growing season following a Vision ${ }^{\circledR}$ application, and Lautenschlager et al. (1995) reported that both brush saw and operational Vision ${ }^{\otimes}$ treatments reduced eastern chipmunk densities for up to three growing seasons after treatment.

As with the other small mammals discussed above, the differences in eastern chipmunk responses may be due in part to differences in soils and productivity between the jack pine- and spruce-dominated study areas. An additional factor, however, may be the treatment plot size used in these studies. Treatment plot size in the jack pine area (Lautenschlager et al. 1995) averaged less than 1 ha, while plot size in this spruce study averaged over 5 ha. Home ranges of eastern chipmunks (usually less than $91 \mathrm{~m}$ across) (Burt and Grossenheider 1980 ) in the jack pine study likely included untreated vegetation, and resident eastern chipmunks simply adjusted their range to avoid the herbicide-treated areas. Eastern chipmunks captured on the larger plots in this study were less likely to have part of their home range untreated, and unless conditions were exceedingly unfavourable they continued to occupy their previous range. Therefore, density reductions were not as common following any treatment in this spruce study area as they were following brush saw cutting and the operational Vision ${ }^{\circledR}$ treatments in the jack pine study area.

Least chipmunk densities increased on herbicide-treated and decreased on cut plots, in relation to control, one and two growing seasons post-treatment. Lautenschlager et al. (1995) reported that least chipmunk densities also were reduced by brush saw cutting and increased following operational Vision ${ }^{8}$ and annual removal with Vision ${ }^{\circledR}$ in the jack pine study area. At both the jack pine and this spruce study areas, least chipmunks seem to favor the more open vegetation character created by the herbicide treatments, but respond negatively to the seemingly equally open character following brush cutting. This response may be due to the physical obstruction caused by the cut-stem litter, the associated increased near-ground relative humidity (Reynolds et al. 1997) or decreased near-ground temperature (Reynolds et al. 1997), terrestrial predator avoidance associated with ground-level visibility, or interactions among these factors.

Milton and Towers (1990) reported increased meadow vole numbers in Vision ${ }^{\circledR}$-treated areas, both naturally regenerated and plantations, three to five years post-treatment. In this study meadow vole densities increased, relative to untreated controls, following the Release ${ }^{\otimes}$ treatment during the first and second post-treatment growing seasons. During this time densities on control, Vision ${ }^{8}$, brush saw, and Silvana Selective plots decreased. Meadow voles are commonly found in grassy habitat, and their food consists mainly of grass and sedge (Burt 1957); therefore, it is not surprising that although there was a general decrease in vole numbers following all treatments, reductions were least on Release ${ }^{\circledR}$ plots where grass cover increased dramatically (5.1 times pre-treatment) (Bell et al. 1996b).

Lautenschlager (1993) concluded that small mammal responses to herbicides are species specific. Some species are unaffected, while some select and others avoid herbicide-treated areas. Small mammal density changes are directly associated with each species' habitat requirements. Some species commonly invade recently disturbed areas where early successional vegetation predominates, while others, although found in these early successional communities, are more commonly found in older seral types.

As with herbicides, small mammal responses to alternative conifer release treatments are species specific, and only the Silvana Selective treatment seems to have eliminated a species (meadow vole) from treated sites. In general, densities simply change, sometimes significantly, in relation to specific alternatives. No alternative maintained consistently high densities of all of the common small mammals in the Fallingsnow small mammal community. During the first two growing seasons after treatment densities of Sorex spp. (cinereus and hoyi combined) were higher on brush saw plots; red-backed voles were highest on control plots; deer mice were highest on Silvana Selective plots; least chipmunks highest on Vision ${ }^{\circledR}$ plots; and meadow voles highest on Release ${ }^{\circledR}$ plots. Artic shrew densities were highest on herbicide (Release ${ }^{\circledR}$, Vision $^{\circledR}$ ) plots during the first post-treatment growing season, but highest on brush saw plots during the second post-treatment growing season. Densities of short-tailed shrews decreased dramatically but without a treatment-related pattern. Eastern chipmunk densities were highest on the Vision ${ }^{\circledR}$ plots during the first posttreatment growing season, but highest on control plots during the second post-treatment growing season.

\section{Conclusions}

This study demonstrates that for small mammals, speciesspecific short-term density changes that follow alternative coniferrelease treatments are in many ways similar to the changes observed following standard conifer release treatments using herbicides. One or more of the species studied responded favourably to each of the conifer release treatments examined. Vegetation changes associated with each treatment type seem responsible for the density changes noted, but it is unclear whether changes in the vegetation itself, associated microclimates, potential food sources, densities of other small mammal species, predator avoidance, or interactions among these were responsible for the differential responses observed. Longer-term monitoring and integration among cooperators in the Fallingsnow ecosystem project, which is ongoing, should allow us to more clearly identify the factors responsible for these changes.

\section{Acknowledgements}

We thank Tom Sullivan, Brian McLaren, Rob Foster, Ian Thompson, two anonymous reviewers, and Wendeline Price for their critical reviews of an earlier draft of this manuscript; Tim Cooey, Andrew Smith, Olivier Pfister, and the dedicated small mammal trapping crews for their hard work and patience; John Winters, Nikki Wood, and Heather Barns for their assistance and logistical support; and Greg Hannah and Din Chen for data manipulation and statistical analysis. This work was supported by the VMAP (Vegetation Management Alternatives Program) under the Sustainable Forestry Initiative, 
Ontario Ministry of Natural Resources, Sault Ste. Marie, Ontario.

\section{References}

Bell, F.W., K.R. Ride, M.L. St-Amour, and M. Ryans. 1997a. Productivity, cost, efficacy and cost efficiency of motor-manual, mechanical, and herbicide release of boreal spruce plantations. For. Chron. 73: $39-46$.

Bell, F.W., R.A. Lautenschlager, R.G. Wagner, D.G. Pitt, J. Hawkins, and K. Ride. 1997b. Motor-manual, mechanical, and herbicide release affect early successional vegetation in northwestern Ontario. For. Chron. 73: 61-68.

Bondrup-Nielsen, S. 1983. Density estimation as a function of live-trapping grid and home range size. Can. J. Zool. 61: 2361-2365. Borrecco, J.E., H.C. Black and E.F. Hooven. 1979. Response of small mammals to herbicide-induced habitat changes. Northwest Science 53(2): 97-106.

Burt, W.H. 1957. Mammals of the Great Lakes Region. University of Michigan Press. 246 p.

Burt, W.H. and R.P. Grossenheider. 1980. A field guide to the mammals - North America north of Mexico (3rd ed.). The Peterson Series, Houghton Mifflin, New York. 289 p.

Campbell, R.A. 1990. Herbicide use for forest management in Canada: Where we are and where we are going. For. Chron. 66: 355-360. Clough, G.C. 1987. Relations of small mammals to forest management in northern Maine. Can. Field-Nat. 101: 40-48.

D'Anieri, P., D.M. Leslie Jr. and M.L. McCormack, Jr. 1987. Small mammals in glyphosate treated clearcuts in northern Maine. Can. FieldNat. 101: 547-550.

Decision Research. 1995. Vegetation management in Ontario's forests: Survey research of public and professional perspectives. Ont. Min. Nat. Resour., Ont. For. Res. Inst., Sault Ste. Marie, Ont. VMAP Tech. Rep. 95-2. 71 p. + append.

Dueser, R.D. and H.H. Shugart Jr. 1978. Microhabitats in a forest-floor small mammal fauna. Ecology 59: 89-98.

Environics Research Group. 1989. 1989 National survey of Canadian public opinion on forestry issues. Unpublished report. Environics Research Group Ltd., Toronto, ON.

Fernald, M.L. 1970. Gray's manual of botany (8th ed.). Van Nostrand Reinhold Co. 1632 p.

Freedman, B. 1991. Controversy over the use of herbicides in forestry, with particular reference to glyphosate usage. J. Environ. Sci. Health C8: 277-286.

Freedman, B., A.M. Poirier, R. Morash and F. Scott. 1988. Effects of the herbicide 2,4,5-T on the habitat and abundance of breeding birds and small mammals of a conifer clearcut in Nova Scotia. Can. Field-Nat. 102: 6-11.

Kurta, A. 1995. Mammals of the Great Lakes Region-Revised Edition. Univ. of Michigan Press, Ann Arbor, MI. 376 p.

Krebs, C.J. 1966. Demographic changes in fluctuating populations of Microtus californicus. Ecol. Monogr. 36: 239-273.

Lautenschlager, R.A. 1986. Forestry, herbicides, and wildlife. Pp. 299-308. In Is good forestry good wildlife management? J.A. Bissonette (ed.). Maine Agr. Exp. Sta., Misc. Publ. 689.

Lautenschlager, R.A. 1993. Response of wildlife to forest herbicide applications in northern coniferous ecosystems. Can. J. For. Res. 23: 2286-2299.

Lautenschlager, R.A., C. Hollstedt and F.W. Bell. 1995. Effects of herbicide, manual, and annual release of young jack pine on vegetation and small mammals in northwestern Ontario. New Zealand Forest Research Institute Bulletin No. 192: 149-151.
Lautenschlager, R.A., F.W. Bell, R.G. Wagner and J.A. Winters. 1997. The Fallingsnow Ecosystem Project: Comparing conifer release alternatives in northwestern Ontario. For. Chron. 73: 35-38. McMillan, L.M., J.F. Connor, H.R. Timmermann, J.G. McNicol and C.S. Krishka. 1990. Small mammal and lesser vegetation response to glyphosate tending in North Central Ontario. Ont. Min. Nat. Resour., Northwestern Ont. For. Tech. Devel. Unit, Tech Rep. No. $57.28 \mathrm{p}$.

Miller, D.H. and L.L. Getz. 1977. Factors influencing local distribution and species diversity of forest small mammals in New England. Can. J. Zool. 55: 806-814.

Milton, G.R. and J. Towers. 1990. Relationships of songbirds and small mammals to habitat features on plantation and natural regeneration sites. St. Mary's River Forestry-Wildlife Project, Can. Inst. For. and NS Dept. Nat. Resour., Antigonish, NS. 52 p. + append. Reynolds, P.E., J.A. Simpson, R.A. Lautenschlager, F.W. Bell, A. M. Gordon, D. Buckley and D. Gresch. 1997. Alternative conifer release treatments affect below- and near-ground microclimate. For. Chron. 73: 75-82.

Rowe, J.S. 1972. Forest regions of Canada. Publication No. 1300, Dept. of Env., Can. For. Serv., Ottawa, ON. 172 p.

Runciman, J. B., and T. P. Sullivan. 1996. Influence of alternative conifer release treatments on habitat structure and small mammal populations in south-central British Columbia. Can. J. For. Res. 26: 2023-2034.

Santillo, D.J., D.M. Leslie Jr., and P.W. Brown. 1989. Response of small mammals and habitat to glyphosate application on clearcuts. J. Wildl. Manage. 53: 164-172.

Simpson, J.A., A.M. Gordon, P.E. Reynolds, R.A. Lautenschlager, F.W. Bell, D. Gresch and D. Buckley. 1997. Influence of alternative conifer release treatments on soil nutrient movement. For. Chron. 73: 69-73.

Stewart, R.E., L.L. Gross and B.H. Honkala. 1984. Effects of competing vegetation on forest trees: a bibliography with abstracts. USDA For. Serv. Gen. Tech. Rep. WO-43.

Sullivan, T.P. 1990. Demographic responses of small mammal populations to a herbicide application in coastal coniferous forest: Population density and resiliency. Can. J. Zool. 68: 874-883.

Sullivan, T.P. and D.S. Sullivan. 1982. Response of small mammal populations to a forest herbicide application in a 20 -year-old plantation. J. Appl. Ecol. 19: 95-106.

Thompson, D.G., D.G. Pitt, B. Staznik, N.J. Payne, D. Jaipersaid, R.A. Lautenschlager and F.W. Bell. 1997. On-target deposit and vertical distribution of aerially-released herbicides. For. Chron. 73: 47-59.

Wagner, R.G. 1992. Vegetation Management Alternatives Program: Program Prospectus. Ontario Ministry of Natural Resources, Ontario Forest Research Institute, Sault Ste. Marie, ON.

Wagner, R.G. 1993. Research directions to advance forest vegetation management in North America. Can. J. For. Res. 23: 2317-2327. Walstad, J.D. and F.N. Dost. 1984. The health risks of herbicides in forestry: a review of the scientific record. For. Res. Lab., Oregon State Univ., Corvallis. Spec. Publ. 10.

Walstad, J.D. and P.J. Kuch. 1987. Forest Vegetation Management for Conifer Production. John Wiley \& Sons, New York. 523 p. Yahner, R.H. 1986. Microhabitat use by small mammals in evenaged forest stands. Am. Midl. Nat. 115: 174-180. 